\title{
Covid-19 Sürecinde Turist Rehberlerinin Çalışma Motivasyonları ve Yaşam Doyumlarının Analizi*
}

\author{
Analysis of Tourist Guides' Job Motivation and Life Satisfaction in the Covid-19 \\ Process
}

\author{
Arş. Gör. Öznur ÇETINKAYA \\ İstanbul Gelişim Üniversitesi, İktisadi, İdari ve Sosyal Bilimler Fakültesi, Türkiye \\ Istanbul Gelisim University, Faculty of Economics, Administrative and Social Sciences, Turkey \\ E-Mail: ocetinkaya@gelisim.edu.tr
}

Prof. Dr. Füsun İSTANBULLU DiNÇER İstanbul Üniversitesi, İktisat Fakültesi, Türkiye Istanbul University, Faculty of Economics, Turkey

E-Mail: istanbul@istanbul.edu.tr

$\ddot{O} z$

Amaç ve Önem: Covid-19 sürecinde ulusal ve uluslararası anlamda uygulanan kısıtlamalar, ekonomik zorluklar turizm faaliyetlerini durma noktasına getirmiştir. Bu zorlu süreçte oteller, acenteler ayakta durmakta zorlanırken turist rehberleri de devletin sunduğu destek kredi paketinden yararlanmaya çalışmıştır. Bu süreçte rehberlerin hala az sayıda da olsa tura çıktı̆̆ı, çalıştığı bilinmektedir. Ancak içinde bulunulan durumda rehberlerin çalışma motivasyonunun ve yaşam doyumlarının ne durumda olduğu merak konusudur. $\mathrm{Bu}$ çalışmanın amacı Covid-19 sürecinde rehberlerin çalışma motivasyonlarını ve yaşam doyumlarını analiz etmek ve aralarındaki ilişkiyi ortaya koymaktır.

Yöntem: Araştırma kapsamında kartopu örnekleme tekniği ile 302 adet anket çevrimiçi form olarak toplanmış; çarpıklık basıklık değerleri incelenerek fark testleri, açıklayıcı ve doğrulayıcı faktör analizi, yol analizi, regresyon değerleri ile değişkenlerin yapısı ve ilişki durumu ortaya koyulmuştur.

Bulgular: Rehberlerin çalışma motivasyonları ile yaşam doyumları arasında pozitif bir iliş̧i olduğu bu bağlamda motivasyon yüksek olursa yaşam doyumunun da yüksek hissedileceği sonucuna ulaşılmıştır.

Özgünlük/Bilimsel Katkı: Covid-19 süreci ile birlikte rehberlerin çalışma motivasyonlarının, literatürdeki araştırmalardan farkl1lık göstererek, zevk ve eğlence boyutuyla öne çıktı̆̆ görülmüştür.

Anahtar Kelimeler: Covid-19, turist rehberleri, motivasyon, yaşam doyumu.

Makale Türü: Araştırma makalesi

\begin{abstract}
Purpose and Importance: National and international restrictions and economic difficulties in the Covid-19 process brought tourism activities to a halt. During this difficult period, while hotels and agencies had difficulty in standing, tourist guides tried to benefit from the support loan package offered by the government. In this process, it is known that the guides still went on tours and worked in a small number. However, it is a matter of curiosity about the job motivation and life satisfaction of the guides in the current situation. The purpose of this study is to analyze the job motivations and life satisfaction of tourist guides in the Covid-19 process and to reveal the relationship between them.
\end{abstract}

Methodology: Within the scope of the research, 302 questionnaires were collected as online forms using the snowball sampling technique; skewness and kurtosis values were examined, difference tests, explanatory and

\footnotetext{
Atıf için (for cited); Çetinkaya, Ö. ve İstanbullu Dinçer, F. (2021). Covid-19 sürecinde turist rehberlerinin çalışma motivasyonları ve yaşam doyumlarının analizi, Turist Rehberliği Dergisi, 4(1), 19-32.

* Bu çalışma Öznur Çetinkaya'nın "Profesyonel Turist Rehberlerinin İş-Yaşam Dengesi ve Tükenmişlik Düzeylerinin Çalışma Motivasyonuna Etkisi” isimli doktora tezinden üretilmiştir.
} 
confirmatory factor analysis, path analysis, regression values were examined and the structure of the variables and their relationship status were revealed.

Findings: It has been concluded that there is a positive relationship between the job motivation and life satisfaction of the guides. In this context, if motivation is high, life satisfaction will be felt high.

Orginality/Value: It has been observed that with the Covid-19 process, the job motivation of the tourist guides, differs from the studies in the literature, stands out with its pleasure and entertainment dimension.

Keywords: Covid-19, tourist guides, motivation, life satisfaction.

Paper Type: Research article

\section{Giriş}

Turizm sektörü savaşlardan, ekonomik krizlerden, politik sorunlardan çok çabuk etkilenen, kırılgan bir yapıdadır. Sars, Ebola, Mers, Domuz Gribi gibi hastalıkların etkili olduğu bölgelerde turizm hareketliliği ciddi oranda azalmış ve bazı bölgelerde durma noktasına gelmiştir (Wen vd., 2005; Kongoley-Mih, 2014; Haque \& Haque, 2018; Joo vd., 2019; İbiş, 2020). Covid-19 salgını tüm dünyayı etkisi altına alarak dünya çapında (15 Mart 2021 itibariyle) 119,603,761 vaka sayısı ve 2,649,722 ölüme neden olmuştur (Dünya Sağlık Örgütü, 2021). Küresel anlamda ekonomik, sosyal, politik etkilere sebep olan Covid-19 salgını, turizm endüstrisini direkt olarak etkilemiştir. 2020 yaz sezonunda alınan önlemler ve düşen vaka sayıları ile turizm ve hizmet sektörü için kısa süreli bir hareketlilik oluşmuş ancak sonbahar ile birlikte yükselen vaka sayıları ile kısıtlamalar yeniden uygulanmaya başlamıştır.

Uygulanan kısıtlamalar ve önlemler çerçevesinde turist rehberleri az sayıda tura çımış veya hiç çalışamamıştır. Kültür ve Turizm Bakanlığı 20 Nisan 2020 tarihinde aktif olarak çalışan, ruhsatlı turist rehberleri için destek kredi paketini açıklamıştır. Ancak Covid-19 süreci veya bu gibi politik, ekonomik krizlerin yaşandığı dönemlerde rehberler devletten yeterli desteği göremediklerini belirtmektedirler (İlhan \& Soybal1, 2018; Düzgün \& Kurt, 2020). Covid-19 süreci ile birlikte çalışamayan ve yeterli desteği göremediklerini belirten turist rehberlerinin çalışma motivasyonları sorgulanması gereken bir konudur. Bireyleri motive eden araçlar mesleklerine ve kişisel özelliklerine göre değiş̧iklik göstermektedir. Turist rehberlerini motive eden araçlar ödül, ücret ve promosyon gibi ekonomik araçlardır (Köroğlu \& Avcıkurt, 2014; Erkol Bayram, 2017). Yaşam doyumu da motivasyon gibi öznel değişkenlere bağlıdır. Kişinin öznel kıstaslarla yaşamını değerlendirmesi ve standart koşullarla kıyaslaması, yaşam doyumunu açıklamaktadır (Diener vd., 1985). Kişi, hayatını değerlendirirken ne ürettiğinin, hayata ne kattığının, mesleğinin de değerlendirmesini yapmaktadır. Meslek, yaşam doyumu sağlanmasında önemli bir faktördür. Ünal vd., (2001) yaptıkları çalışmada, mesleği aracılığıyla doyum sağlamış bireyin, yaşam doyumunun yüksek olacağını belirtmektedirler.

Çalışmanın amacı, Covid-19 sürecinde turist rehberlerinin çalışma motivasyonları ve yaşam doyumlarının ne düzeyde olduğunu tespit etmek ve motivasyonun yaşam doyumu üzerindeki etkisini analiz etmektir. Öncelikle motivasyon ve yaşam doyumuna ilişkin alan yazın bilgisi verilmiş ardından araştırmanın yöntem ve bulgusu açıklanmıştır.

\section{Literatür taraması}

\subsection{Motivasyon}

Motivasyon, kişisel özellikler ile ilintili ve davranışları direkt etkileyen bir olaydır. Bireyin yaptığı iş ile beklentileri, kişisel özellikleri arasında yakın ilişki bulunmaktadır. Kişi, uygun ortamda, kendisi için anlamlı ve değerli iş yaptığına inanırsa o iş için motive olacaktır (Koçel, 2018). Motivasyon, bireyin davranışlarını direkt etkileyen biyolojik, psikolojik, sosyal ve bilişsel faktörlerle ilgili olan, istek ve ihtiyaçları gidermek için harekete geçecek düzeyde isteklenme ve bu sürecin tamamıdır (Köse, 2019). 
Motivasyon kavramını açıklamaya yönelik ortaya koyulmuş teoriler, kapsam teorileri ve süreç teorileri olmak üzere ikiye ayrılmaktadır. Kapsam teorileri içsel faktörlere ağılık verirken süreç teorileri dışsal faktörlere ağırlık vermektedir. Kapsam teorileri, kişinin içinde bulunan ve içsel olarak onu güdüleyen faktörleri açıklamaktadır ve geleneksel teoriler olarak da tanımlanmaktadır. En bilinen kapsam teorileri, Maslow'un İhtiyaçlar Hiyerarşisi, Herzberg'in Çift Faktör Teorisi, Alderfer'in ERG Teorisi ve McClelland'ın Başarı İhtiyacı Teorisidir. Süreç teorileri modern teoriler olarak belirtilmektedir ve içsel faktörlerin yanı sıra bireyin davranışını etkileyen çevresel faktörlere odaklanmaktadır. En bilinen süreç teorileri, Eşitlik Teorisi, Bekleyiş Teorisi, Amaç Teorisi ve Davranış Şartlandırma Yaklaşımıdır (Yeşil, 2016). Ortaya koyulan her teorinin birbiriyle benzer ve farklı yönleri bulunmaktadır. Bazı teoriler genel insani özellikler üzerinden açıklamaya yaparken bazıları kişisel farklılıklar üzerinde durmuştur.

Motivasyon içsel veya dişsal faktörlerden etkilenmektedir. İçsel olarak, bireysel nitelikler ve deneyimler etki yaratırken dişsal olarak kişinin içinde bulunduğu örgüt, toplum, sosyal ve kültürel çevre etki yaratmaktadır (Erkol, 2015). İç motivasyon, motivasyon hedefine yönelik algılanan değer ve haz ile ilgilidir, dış motivasyon ise motivasyon hedefine yönelik eylem sonucunda bireyin etkisini sorgulamaktadır (Ingram vd., 1989). Çalışan bireyin iç motivasyonu yüksek olduğunda yaptığı işten zevk alır, eğlenerek işini yapar. Dış motivasyonu yüksek olan birey, işi değil sonucuna yönelik hareket eder ve sonucunda ödül, onay, suçluluktan kaçınmak için iş yapar (Çivilidağ \& Şekercioğlu, 2017). Motivasyonun işletme açısından stratejik önemi bulunmaktadır. Motive olan çalışan şirket için yeteneğinin tümünü kullanmak isteyecek, sorumluluk almak isteyecektir (Putra, 2019) böylece şirket karlılığına etkisi büyük olacaktır (Huggins vd., 2016). Can ve Koç (2018)'a göre motivasyonda kişisel özelliklerin göz ardı edilmemesi, her bireyin ihtiyacının farklı olduğu ve buna yönelik motivasyon araçlarının kullanılması gerektiği bilinmelidir. Üretkenliği arttırmak, işyeri stresini azaltmak ve özgüveni arttırmak için birç̧ok motivasyon araç ve teknikleri bulunmaktadır (Uzonna, 2013). $\mathrm{Bu}$ araç ve teknikler bireysel özelliklerine göre kişilerde farklı yoğunlukta etkiler yaratmaktadır. Bireylerin içsel motivasyonuna etki eden faktörlerden bazıları karar alma yeteneği, liyakat, işe katılım ve iş merakıyken, dış motivasyona etki eden faktörlerden bazıları, rekabetçi ortam, değerlendirme uygulamaları olabilmektedir. Ayrıca kişiye saygı duyulması, takdir edilmesi, gurur duyulmas1, cesaretlendirilmesi motive eden unsurlardır (Azar \& Shafighi, 2013). Motivasyon araçları ekonomik, psiko-sosyal ve örgütsel-yönetsel olmak üzere üçe ayrılarak incelenebilmektedir. Farklı meslek grupları ve kişisel özelliklere göre motivasyon araçlarının etkinliği değişkenlik göstermektedir. Yapılan araştırmalar (Köroğlu \& Avcıkurt, 2014; Erkol Bayram, 2017) turist rehberlerinin ekonomik araçlarla motive olduklarını ortaya koymaktadır.

\subsection{Yaşam Doyumu}

Yaşam doyumu, bireyin kendi yaşamına gösterdiği duygusal tepki olarak belirtilmektedir (Dikmen, 1995). Bu tepki mutluluk, moral gibi yaşamda değişik açılardan iyi olma halini ifade etmektedir ve olumlu duygunun olumsuz duyguya egemen olmasıdır (Avşaroğlu vd., 2005). Yaşam doyumu, yaşamın farklı alanları ile ilgili olabilmektedir. Günlük yaşamda hissedilen doyum, hedeflere ulaşılması, olumlu düşünen kişilik yapısına sahip olma, ekonomik, güvenlik ve sosyal açılardan 'iyi' hissedilmesi yaşam doyumunu etkilemektedir (Ülker Tümlü \& Recepoğlu, 2013). Yaşam doyumu 1960'lı yıllarda zihinsel bağlamda araştırılan bir kavram olarak ele alınmış, 70'li yıllarda Amerikan Sosyal Göstergeler araştırmalarında ana tema olarak bahsedilmiştir. Yaşam doyumu, bireyin sahip olduğu toplumsal kaynakların (ekonomik iyilik, sosyal eşitlik, politik özgürlük, kültürel zenginlik...), kişisel kaynakların (sosyal durum, maddi mülkiyet, politik etki, sosyal prestij, aile bağları...), bireysel yeteneklerin (fiziksel iyilik, ruhsal dayanıklılık, sosyal kapasite, entelektüel yetenek...) ihtiyaç, saldırı, yalnızlık, mücadele, çirkinlik gibi durumları karşılaması ile ortaya çıkan doyum, güven, saygı coşku deneyimleri ile değerlendirilmesidir (Veenhoven, 1996). 
Yaşam doyumu, temel olarak bireyin kendi yaşamını standart kabul ettiği kıstaslar çerçevesinde değerlendirmesidir. Bu değerlendirme sonucu, eğer birey yaşamını standartlara uygun bulursa yaşam doyumu hissedebilmektedir. Yaşam doyumu, bireyin hayatının farklı alanlarında yaşadığı iyi oluş hali ile ilgilidir (Appleton \& Song, 2008). Öznel iyi oluş, kişinin yaşamını bilişsel ve duygusal olarak değerlendirmesi ve bu değerlendirme sonucunda olaylara verdiği duygusal tepkiler ve doyum durumu olarak belirtilmektedir. Kişiler olumlu duygusal hissettiklerinde ve yaşamlarından memnun olduklarında yüksek bir öznel iyi oluş hali içerisine girmektedirler (Diener vd., 1985). İyi oluş hali içinde olamayan, yaşam doyumu sağlayamayan birey, duygusal yoksunluk duygusu ile karşlaşabilmektedir (Kara vd., 2014). Yaşam doyumu sağlamada meslek hayatı ve üretkenlik önem arz etmektedir. Yaptığı işten doyum sağlayan birey, daha fazla yaşam doyumu daha az tükenmişlik hissedecektir (Ünal vd., 2001). Çalışma yaşamı ve çalışma dışı yaşam ilişkisi incelendiğinde çalışma alanından alınan doyumun çalışma dışı yaşam doyumu ile birlikte toplam yaşam doyumunu oluşturduğunu belirtmek mümkündür (Keser, 2011). Yaşam doyumu ile ilişkili olan iș doyumunu bireysel özelliklerin, deneyimlerin, örgütteki statü, ücret ve çalıșma koșullarının etkilediği belirtilmektedir (Akgündüz, 2013). Alrawadieh vd., (2018) yaptıkları çalışmada turist rehberlerinin yaşam doyumlarının iş yaşam kaliteleri ile pozitif şekilde ilişki olduğunu ortaya koymuşlardır. $\mathrm{Bu}$ durumda iş yaşamında memnun olan rehber, yaşam doyumunu da yüksek hissedecektir.

Yapılan alan yazın taraması ile motivasyon ve yaşam doyumu kavramlarına yönelik yapılmış araştırmalar incelenerek teorik altyapı sorgulanarak "H1: Profesyonel turist rehberlerinin çalışma motivasyonlarının yaşam doyumları üzerinde etkisi vardır" hipotezi oluşturulmuştur.

\section{Yöntem}

Araştırma kapsamında veri toplamak için anket tekniği tercih edilerek öncelikle katılımcılara araştırma bilgi ve içeriği verilmiş ardından cinsiyet, medeni durum, eğitim düzeyi, yaş ve mesleki deneyimi kapsayan demografik bilgileri paylaşmaları istenmiştir. Ardından motivasyon ve yaşam doyumu ölçekleri verilmiştir. Motivasyonu ölçmek için Miao vd., (2007)'nun geliştirdiği 16 ifadeli, iç motivasyonu zorluklar ve eğlence alt boyutlarıyla, dış motivasyonu ise mükafat ve tanınırlık alt boyutlarıyla ölçen ifadeler kullanılmıştır. Motivasyon ölçeğinin 'Nadiren maaş veya kazanç düşünürüm' ifadesi ters kodlama yapılmış, analize uygun hale getirilmiştir. Yaşam doyumunu ölçek için Diener, Emmons, Larsen ve Griffin tarafından 1985 yılında geliştirilmiş olan, beş ifadeli ölçek kullanılmış ve 7'li Likert ölçeği ile ölçülmüştür.

Çalışma kapsamında veri toplamak için motivasyon ve yaşam doyumu kavramlarına dair oluşturulmuş ölçekler, profesyonel turist rehberlerine uyarlanarak tek ankette birleştirilerek, çevrimiçi form olarak e-mail aracılığıyla rehberlere yollanmıştır. Öncelikli hedef elden ve online anket toplanması olarak belirlenmişken yaşanan Covid-19 salgını nedeniyle rehberlerle birebir temas sağlanamamış bu yüzden veri yalnızca online anket dağıtımı ile sağlanmıştır. Bu noktada, turist rehberleri meslek odalarından yardım istenmiş olup, maksimum düzeyde katılım sağlanması hedeflenmiştir. Türkiye Turist Rehberleri Birliği’ne bağl 7 ülkesel ve 6 bölgesel meslek odasından yardım istenmiştir. Kartopu örnekleme, zengin veri elde edilmesini sağlayacak kişi ve kurumlarla iletişime geçilerek onlar aracılığıyla anket formunun dağıtımının sağlanmasıdır. Zincir örnekleme de denilen bu teknikte, araştırmacı, örnekleme girmeye uygun olan kişileri bulup aynı ölçütte olan kişilere bu kişiler aracılığıyla ulaşmaya çalışır (Baltacı, 2018). Bu çalışmada kartopu örnekleme tekniği kapsamında rehberlik odaları ile iletişime geçilerek araştırma bilgisi verilmiş ve anket formunun eylemli turist rehberlerine iletilmesi rica edilmiştir. Oluşturulan anket formu, 06/08/2020103972 tarih ve sayılı İstanbul Üniversitesi Etik Kurul onayı ile bilimsel açıdan uygun bulunmuş ve veri toplama işlemi 10 Ağustos- 10 Ekim 2020 tarihleri arasında yürütülmüştür.

$\mathrm{Bu}$ sayede 302 adet anket geri dönüşü sağlanmıştır. Anket formu çevrimiçi form olarak oluşturulduğundan her ifadenin cevabı zorunlu kılınmış ve kayıp veri alınmamıştır. Verilerin 
Turist Rehberliği Dergisi (TURED) \& Yıl. 2021, Cilt. 4, Sayı. 1

Journal of Tour Guiding (JOTOG) \& Year. 2021, Volume. 4, Issue. 1

toplanması ve analize hazır hale getirilmesinden sonra öncelikle çarpıklık basıklık değerleri incelenerek verilerin normal dağılımı sorgulanmıştır. Ardından demografik verilerin ölçeklerde fark yaratıp yaratmadığı araştırılmış bu kapsamda iki gruplu verilerde t testi, 3 ve daha fazla gruplu demografik verilerde Anova testi yapılmıştır. Motivasyon ve yaşam doyumu ölçekleri orijinal kaynaklarından alınarak önce açıklayıcı ardından doğrulayıcı faktör analizleri yapılmıştır. Ölçek yapılarının doğrulanması sonrası yapısal eşitlik modellemesi ile değişkenler arasındaki etki ve ilişki durumu araştırılmıştır.

\section{Bulgular}

Öncelikle verilerin normal dağılımını test etmek amacıyla çarpıklık (skewness) basıklık (kurtosis) değerleri incelenmiş ve literatürde önerilen sınırlar içinde kalındığı görülmüştür (Tablo1). Çarpıklık-basıklık değerleri araştırmacılar tarafından farklı sınırlarda kabul görmüştür. Buna göre, Hair vd. (2013) değerlerin +1 ile -1 sınırları arasında kalmasını uygun görürken, Tabachnick ve Fidell (2013) değerlerin +1.5 ile -1.5 arasında kalmasını kabul etmiş, George ve Mallery (2010) ise belirtilen değerlerin +2 ile -2 arasında olmasını gerektiğini belirtmektedir.

\section{Tablo 1}

Ölçek Ifadelerinin Çarpıklık Basıklık Değerleri

\begin{tabular}{|c|c|c|c|c|}
\hline Motivasyon & Ort. & Std. S. & Çarpıklık & Basıklık \\
\hline İşimde yeni karşılaştı̆̆ım sorunları çözmekten haz duyarım. & 5,58 & 1,527 & $-1,207$ & ,845 \\
\hline İşimdeki karmaşık sorunları çözmeye çalışmaktan haz duyarım. & 5,42 & 1,666 & $-1,061$ & 244 \\
\hline $\begin{array}{l}\text { İşe dair sorunlar ne kadar büyükse, çözmeye çalışırken duyduğum haz } \\
\text { o kadar büyüktür. }\end{array}$ & 4,52 & 1,888 &,- 366 &,- 887 \\
\hline $\begin{array}{l}\text { İşimin benim yeteneklerimi ve bilgimi arttıracak firsatlar sağlamasını } \\
\text { isterim. }\end{array}$ & 6,30 & ,957 & $-1,345$ & 1,090 \\
\hline Benim için önemli olan yaptığım işte eğlenmektir. & 5,58 & 1,489 & $-1,038$ &, 585 \\
\hline $\begin{array}{l}\text { İşim aracılığıyla kendimi ifade edebilecek bir yola sahip olmam } \\
\text { benim için önemlidir. }\end{array}$ & 6,20 & 1,033 & $-1,290$ & 1,116 \\
\hline $\begin{array}{l}\text { İşin sonucu ne olursa olsun, eğer yeni bir deneyim kazanmış } \\
\text { hissediyorsam memnun olurum. }\end{array}$ & 6,09 & 1,155 & $-1,342$ & 1,453 \\
\hline Benim için en çok eğlendiğim şeyi yapabilmem önemlidir. & 5,70 & 1,424 & $-1,050$ & 641 \\
\hline $\begin{array}{l}\text { İşim aracilığıyla kazanabileceğim para sayesinde güçlü şekilde } \\
\text { motive olurum. }\end{array}$ & 6,00 & 1,074 & $-1,158$ & 1,878 \\
\hline $\begin{array}{l}\text { Kendime koyduğum promosyon hedeflerinin farkında olarak şevkle } \\
\text { çalışırım. }\end{array}$ & 5,58 & 1,624 & $-1,252$ & ,947 \\
\hline Nadiren maaş veya promosyon düşünürüm. & 4,80 & 1,761 &,- 405 &,- 790 \\
\hline $\begin{array}{l}\text { Kendime koyduğum gelir hedeflerinin farkında olarak şevkle } \\
\text { çalışırım. }\end{array}$ & 5,64 & 1,412 & $-1,260$ & 1,602 \\
\hline $\begin{array}{l}\text { Diğer insanlar tarafından tanınır olabilmek beni güçlü şekilde motive } \\
\text { eder. }\end{array}$ & 5,57 & 1,559 & $-1,097$ & ,594 \\
\hline $\begin{array}{l}\text { İşimde gerçekten ne kadar iyi olabileceğimi diğer insanların da } \\
\text { görmesini isterim. }\end{array}$ & 5,44 & 1,697 & $-1,052$ & ,251 \\
\hline Bana göre başarı, diğer insanlardan daha iyi olabilmektir. & 3,74 & 2,008 &, 160 & $-1,156$ \\
\hline $\begin{array}{l}\text { İşimdeki performansıma yönelik diğer insanların nasıl tepki vereceği } \\
\text { beni kaygılandırır. }\end{array}$ & 3,93 & 1,936 &,- 101 & $-1,161$ \\
\hline \multicolumn{5}{|l|}{ Yaşam Doyumu } \\
\hline Çoğu açıdan hayatım olması gerekene yakındır. & 5,03 & 1,431 &,- 764 & 455 \\
\hline Yaşam koşullarım mükemmeldir. & 4,43 & 1,412 &,- 674 &,- 118 \\
\hline Hayatımdan memnunum. & 5,39 & 1,337 & $-1,114$ & 1,117 \\
\hline Şimdiye kadar hayatımda istediğim önemli şeylere sahip oldum & 5,24 & 1,396 &,- 727 &, 036 \\
\hline $\begin{array}{l}\text { Eğer hayatımı baştan yaşayabilseydim, neredeyse hiçbir şeyi } \\
\text { değiştirmezdim. }\end{array}$ & 4,42 & 1,822 &,- 379 &,- 801 \\
\hline
\end{tabular}

Demografik değişkenlere göre motivasyon ve yaşam doyumu ölçeklerinde farklılık oluşup oluşmadığının kontrolü için iki gruplu değişkenlerde bağımsız örneklem t testi, üç veya daha fazla 
Turist Rehberliği Dergisi (TURED) \& Yıl. 2021, Cilt. 4, Sayı. 1

Journal of Tour Guiding (JOTOG) \& Year. 2021, Volume. 4, Issue. 1

gruplu değişkenler için Anova analizi yapılmıştır. Evli olan turist rehberlerinin çalışma motivasyonun $(\overline{\mathrm{x}}: 5,48)$ bekar olanlara $(\overline{\mathrm{x}}: 5,24)$ kıyasla daha yüksek olduğunu görmek mümkündür. Ayrıca 20-35 yaş aralığındaki turist rehberlerinin çalışma motivasyonu diğer yaş gruplarına göre daha yüksektir ( $\overline{\mathrm{x}}$ : 5,51). Yaşam doyumu ölçeğinde medeni durumda fark olduğu gözlenmiş, evli olan turist rehberlerinin yaşam doyumunun daha yüksek olduğu belirlenmiştir ( $\mathrm{x}: 5,03)$ (Tablo2).

Tablo 2

Demografik Değişkenlerin Ölçeklere Göre Fark Analizleri

\begin{tabular}{|c|c|c|c|c|c|c|}
\hline Ölçekler & & Özellikler & $\overline{\mathrm{x}}$ & s.s. & $\mathrm{F} / \mathrm{t}$ & $\mathrm{P}$ \\
\hline \multirow{14}{*}{ 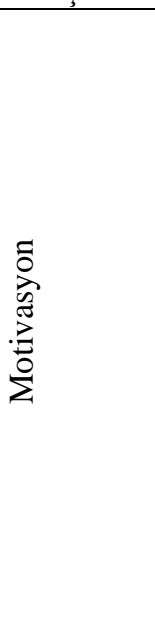 } & \multirow[t]{2}{*}{ Cinsiyet } & Erkek & 5,44 & ,790 & \multirow{2}{*}{$-1,59$} & \multirow{2}{*}{, 112} \\
\hline & & Kadın & 5,28 & ,844 & & \\
\hline & Medeni Durum & $\begin{array}{c}\text { Bekar } \\
\text { Evli }\end{array}$ & $\begin{array}{l}5,24 \\
5,48\end{array}$ & $\begin{array}{l}, 880 \\
.741\end{array}$ & 2,59 &, $010^{*}$ \\
\hline & \multirow{3}{*}{ Eğitim Düzeyi } & Lisans & 5,44 & 803 & \multirow{3}{*}{2,99} & \multirow{3}{*}{, 051} \\
\hline & & Lisansüstü & 5,12 & ,781 & & \\
\hline & & Önlisans veya Lise & 5,38 & ,849 & & \\
\hline & \multirow{3}{*}{ Yaş } & $20-35$ & 5,51 & ,740 & \multirow{3}{*}{3,67} & \multirow{3}{*}{, $027^{*}$} \\
\hline & & $36-50$ & 5,33 & ,796 & & \\
\hline & & $51-75$ & 5,18 & 956 & & \\
\hline & \multirow{5}{*}{$\begin{array}{l}\text { Mesleki } \\
\text { Deneyim }\end{array}$} & 1 yildan az & 5,44 & ,932 & \multirow{5}{*}{,964 } & \multirow{5}{*}{,428 } \\
\hline & & $1-5$ y1l & 5,54 & 665 & & \\
\hline & & $6-10$ y1l & 5,31 & 698 & & \\
\hline & & $11-20$ yll & 5,24 & 917 & & \\
\hline & & $21-45 \mathrm{y} 11$ & 5,36 & 651 & & \\
\hline \multirow{15}{*}{ 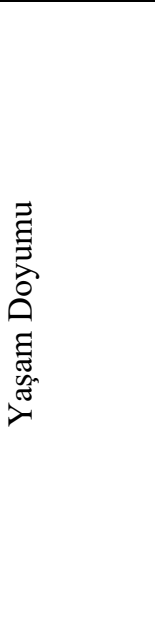 } & \multirow{2}{*}{ Cinsiyet } & Erkek & 4,92 & 1,09 & \multirow{2}{*}{,- 374} & \multirow{2}{*}{,708 } \\
\hline & & Kadın & 4,86 & 1,39 & & \\
\hline & \multirow{2}{*}{ Medeni Durum } & Bekar & 4,73 & 1,27 & \multirow{2}{*}{2,11} & \multirow{2}{*}{, $035^{*}$} \\
\hline & & Evli & 5,03 & 1,15 & & \\
\hline & \multirow{3}{*}{ Eğitim Düzeyi } & Lisans & 4,86 & 1,16 & \multirow{3}{*}{1,53} & \multirow{3}{*}{,217 } \\
\hline & & Lisansüstü & 5,17 & 1,28 & & \\
\hline & & Önlisans veya Lise & 4,78 & 1,33 & & \\
\hline & \multirow{3}{*}{ Yaş } & $20-35$ & 4,79 & 1,09 & \multirow{3}{*}{1,35} & \multirow{3}{*}{,259 } \\
\hline & & $36-50$ & 5,04 & 1,18 & & \\
\hline & & $51-75$ & 4,84 & 1,51 & & \\
\hline & \multirow{5}{*}{$\begin{array}{l}\text { Mesleki } \\
\text { Deneyim }\end{array}$} & 1 yildan az & 4,81 & 1,20 & \multirow{5}{*}{1,42} & \\
\hline & & $1-5 \mathrm{y} 1 \mathrm{l}$ & 4,52 & 1,21 & & \\
\hline & & $6-10$ y1l & 4,94 & ,96 & & ,224 \\
\hline & & $11-20$ y 11 & 5,09 & 1,20 & & \\
\hline & & $21-45$ y1l & 5,02 & 1,43 & & \\
\hline
\end{tabular}

*p $<0,05$ düzeyinde anlamlıdır.

Motivasyon ölçeği için açıklayıcı faktör analizi sonucu Miaou vd., (2007) ile uyum göstermekte ve dört faktörlü bir yapı ortaya koymaktadır (Tablo3). Bu faktörler bireylerin işlerine dair olan mücadele motivasyonunu, aldıkları görevlerine yönelik eğlence motivasyonunu, işe dair ödül ihtiyacını ve işin sonucunda tanınma ihtiyacına yönelik motivasyonlarını açıklamaktadır (Miaou vd., 2007). 
Turist Rehberliği Dergisi (TURED) \& Yıl. 2021, Cilt. 4, Sayı. 1

Journal of Tour Guiding (JOTOG) \& Year. 2021, Volume. 4, Issue. 1

Tablo 3

Motivasyon Ölçeği Açılklayıcı Faktör Analizi

\begin{tabular}{|c|c|c|c|c|}
\hline & \multicolumn{4}{|c|}{ Faktör Yükleri } \\
\hline & Ĕglence & Mücadele & Tanınma & Ödül \\
\hline Benim için önemli olan yaptığım işte eğlenmektir. & ,776 & & & \\
\hline $\begin{array}{l}\text { Benim için en çok eğlendiğim şeyi yapabilmem } \\
\text { önemlidir. }\end{array}$ & ,767 & & & \\
\hline $\begin{array}{l}\text { İşim aracılığıyla kendimi ifade edebilecek bir yola sahip } \\
\text { olmam benim için önemlidir. }\end{array}$ & 685 & & & \\
\hline $\begin{array}{l}\text { İşin sonucu ne olursa olsun, eğer yeni bir deneyim } \\
\text { kazanmış hissediyorsam memnun olurum. }\end{array}$ & ,579 & & & \\
\hline $\begin{array}{l}\text { İşimin benim yeteneklerimi ve bilgimi arttıracak } \\
\text { firsatlar sağlamasını isterim. }\end{array}$ & ,433 & & & \\
\hline $\begin{array}{l}\text { İşimdeki karmaşık sorunları çözmeye çalışmaktan haz } \\
\text { duyarım. }\end{array}$ & & ,908 & & \\
\hline $\begin{array}{l}\text { İşimde yeni karşılaştığım sorunları çözmekten haz } \\
\text { duyarım. }\end{array}$ & & 897 & & \\
\hline $\begin{array}{l}\text { İşe dair sorunlar ne kadar büyükse, çözmeye çalışırken } \\
\text { duyduğum haz o kadar büyüktür. }\end{array}$ & & ,806 & & \\
\hline $\begin{array}{l}\text { İşimde gerçekten ne kadar iyi olabileceğimi diğer } \\
\text { insanların da görmesini isterim. }\end{array}$ & & & ,777 & \\
\hline $\begin{array}{l}\text { Bana göre başarı, diğer insanlardan daha iyi } \\
\text { olabilmektir. }\end{array}$ & & & ,768 & \\
\hline $\begin{array}{l}\text { Diğer insanlar tarafından tanınır olabilmek beni güçlü } \\
\text { şekilde motive eder. }\end{array}$ & & & ,719 & \\
\hline $\begin{array}{l}\text { İşimdeki performansıma yönelik diğer insanların nasıl } \\
\text { tepki vereceği beni kaygılandırır. }\end{array}$ & & & 663 & \\
\hline Nadiren maaş veya promosyon düşünürüm. & & & & 654 \\
\hline $\begin{array}{l}\text { Kendime koyduğum promosyon hedeflerinin farkında } \\
\text { olarak şevkle çalışırım. }\end{array}$ & & & & ,648 \\
\hline $\begin{array}{l}\text { Kendime koyduğum gelir hedeflerinin farkında olarak } \\
\text { şevkle çalışırım. }\end{array}$ & & & & ,633 \\
\hline $\begin{array}{l}\text { İsim aracılığıyla kazanabileceğim para sayesinde güçlü } \\
\text { şekilde motive olurum. }\end{array}$ & & & & 601 \\
\hline Varyans & 30,995 & 13,027 & 9,031 & 8,389 \\
\hline Toplam Varyans Açıklama Oranı & & 61, & & \\
\hline Cronbach's Alpha & & ,82 & & \\
\hline KMO & & & & \\
\hline Bartlett Küresellik Testi & & 1938,7 & 000 & \\
\hline
\end{tabular}

İlk faktör olan eğlence motivasyonu toplam varyansın \%30,995'ini açılamakta; ikinci boyut olan mücadele motivasyonu toplam varyansın \%13,027'sini açılamakta; üçüncü faktör olan tanınma motivasyonu toplam varyansın \%9,031'ini; dördüncü faktör ödül motivasyonu olan toplam varyansın \%8,389'unu açıklamaktadır. Bu durumda motivasyon ölçeğinde en etkili ve öne çıan boyutun eğlence motivasyonu boyutu olduğunu belirtmek mümkündür. Faktörleri oluşturan ifadelerin birbirleriyle uyumunu gösteren KMO değeri ,810; Bartlett küresellik testi sonucu anlamlı $(\mathrm{p}<, 000)$ ve Cronbach's Alpha katsayısı ,827 değeri ile ölçeğin güvenilir bir yapıda olduğu saptanmıştır. Toplam varyans açıklama oranı \%61,442 olarak hesaplanmış böylece motivasyon ölçeğine yönelik yapılmış olan açıklayıcı faktör analizinin anlamlı, geçerli sonuçlar ortaya koyduğu belirlenmiştir. 


\section{IIIII) $\odot$}

Turist Rehberliği Dergisi (TURED) \& Yıl. 2021, Cilt. 4, Sayı 1

Journal of Tour Guiding (JOTOG) \& Year. 2021, Volume. 4, Issue. 1

Yapılan ayrışma geçerliliği analizi sonucunda motivasyon ölçeği faktör boyutları arasında düşük (Eğlence-Mücadele: ,402; Eğlence-Tanınma: ,364; Mücadele-Tanınma: ,225; Eğlence-Ödül: ,463; Mücadele-Ödül: ,342; Tanınma-Ödül: ,393) dereceli ilişki olduğu görülmüş ve boyutların kavramsal olarak birbirinden ayrıldığı ortaya konmuştur (Tablo4).

\section{Tablo 4}

Motivasyon Ölçeği Ayrışma Geçerliliği Analizi

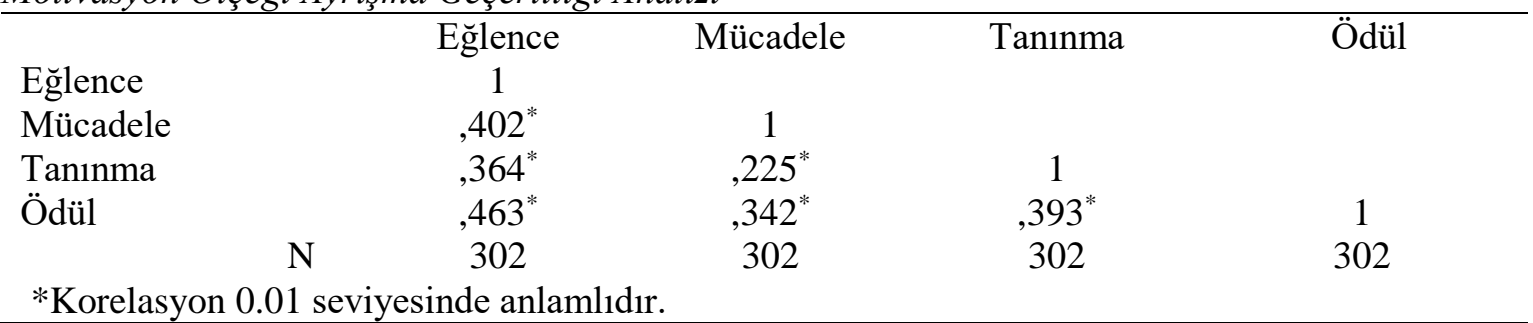

Yaşam doyumu ölçeği açıklayıcı faktör analizi sonucu Diener vd. (1985) gibi tek boyutlu bir yap1 ortaya çıkmıştır. Ölçeğin toplam varyans açıklama oran1 \%68,749'dur. Cronbach Alpha katsayıs1 ile $(, 877)$ ölçeğin güvenilir olduğunu; KMO değeri $(, 855)$ ölçüm yapmada örneklemin yeterli olduğunu göstermektedir. Barlett Küresellik Testi ise, değişkenler arasında ilişkinin anlamlı $(\mathrm{p}<0,05)$ olduğunu göstermektedir (Tablo5).

\section{Tablo 5}

Yaşam Doyumu Ölçeği Açılklayıcı Faktör Analizi

\begin{tabular}{lc}
\hline & Faktör \\
\hline Çoğu açıdan hayatım olması gerekene yakındır. &, 868 \\
Hayatımdan memnunum. &, 856 \\
Şimdiye kadar hayatımda istediğim önemli şeylere &, 843 \\
sahip oldum. & \\
Yaşam koşullarım mükemmeldir. &, 835 \\
Eğer hayatımı baştan yaşayabilseydim, neredeyse &, 738 \\
hiçbir şeyi değiştirmezdim. & \\
Toplam Varyans Açıklama Oranı & 68,749 \\
Cronbach's Alpha &, 877 \\
KMO &, 855 \\
Bartlett Küresellik Testi & $811,353 / 0,000$ \\
\hline
\end{tabular}

Motivasyon ölçeği doğrulayıcı faktör analizi sonucu modelin değerlerinin kabul edilebilir düzeyde olduğu görülmüş ve çıkan faktör yapısı doğrulanmıştır $(\chi 2 /$ sd: 2,18 GFI: 0,93 ; NFI: 0,91;CFI: 0,95; RMSEA: 0,063). Değişkenler arasındaki değerler şekil 1'de görülebilmektedir. Analiz yapılırken 11. ifade olan 'Nadiren maaş veya promosyon düşünürüm' ve 4.ifade olan 'İşimin benim yeteneklerimi ve bilgimi arttıracak firsatlar sağlamasını isterim' ifadeleri analizde düşük ve bulaşık değerlere sahip olmaları nedeniyle analizden çıkarılmıştır. 


\section{IIIII)}

Turist Rehberliği Dergisi (TURED) \& Yıl. 2021, Cilt. 4, Sayı. 1

Journal of Tour Guiding (JOTOG) \& Year. 2021, Volume. 4, Issue. 1

\section{Şekil 1}

Motivasyon Ölçeği Doğrulayıcı Faktör Analizi

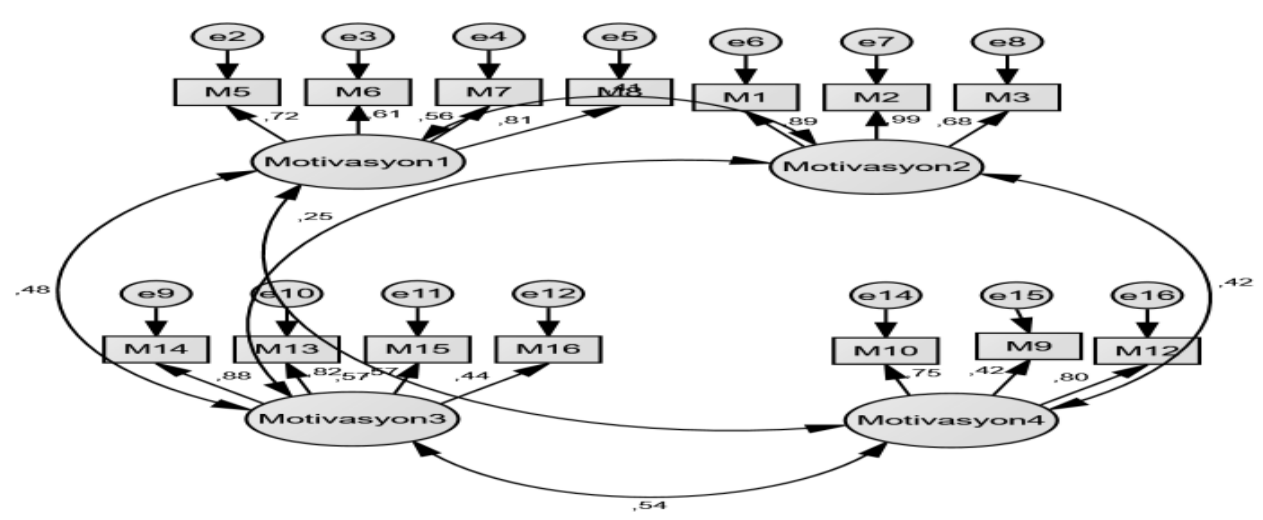

Şekil 2

Motivasyonun Yaşam Doyumuna Etkisi

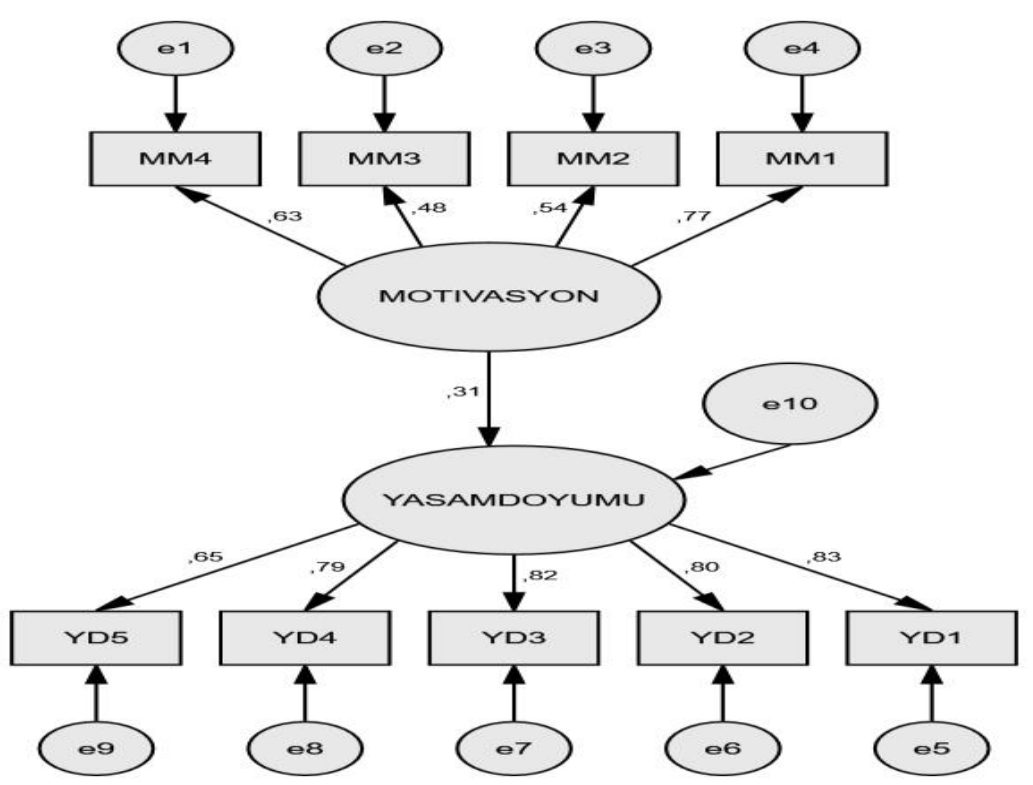

Yapılan yapısal eşitlik modellemesi sonucu çıkan yol analizi Şekil 2'de görülmektedir. Modelin uyum değerleri ki kare nin serbestlik derecesi oranında kabul edilebilir, RMSEA değeri ve CFI, GFI, NFI değerleri kabul edilebilir seviyede bulunmuştur ( $\chi 2$ /sd: 3,027; GFI:0,94; NFI: 0,92; CFI: 0,95; RMSEA: 0,082). 


\section{IIIII)}

Turist Rehberliği Dergisi (TURED) \& Yıl. 2021, Cilt. 4, Sayı. 1

Journal of Tour Guiding (JOTOG) \& Year. 2021, Volume. 4, Issue. 1

Tablo 6

Araştırma Modeli Değerleri

\begin{tabular}{lllcll}
\hline & & & Standart Regresyon Değerleri & \multirow{2}{*}{ Std. Hata } & $\mathrm{p}$ \\
\hline YASAMDOYUMU & $<---$ & MOTIVASYON &, 312 &, 131 & $* * *$ \\
MM4 & $<--$ & MOTIVASYON &, 625 & & \\
MM3 & $<---$ & MOTIVASYON &, 480 &, 153 & $* * *$ \\
MM2 & $<--$ & MOTIVASYON &, 539 &, 173 & $* * *$ \\
MM1 & $<---$ & MOTIVASYON &, 766 &, 143 & $* * *$ \\
YD1 & $<--$ & YASAMDOYUMU &, 833 & & \\
YD2 & $<---$ & YASAMDOYUMU &, 801 &, 060 & $* * *$ \\
YD3 & $<--$ & YASAMDOYUMU &, 822 &, 057 & $* * *$ \\
YD4 & $<---$ & YASAMDOYUMU &, 793 &, 060 & $* * *$ \\
YD5 & $<--$ & YASAMDOYUMU &, 651 &, 083 & $* * *$ \\
\hline
\end{tabular}

$* * * \mathrm{p}<0,05$ düzeyinde anlamlıdır.

Model değerleri ile "H1: Profesyonel turist rehberlerinin çalışma motivasyonlarının yaşam doyumları üzerinde etkisi vardır" hipotezi kabul edilmiştir. Çalışma motivasyonunun yaşam doyumu üzerinde pozitif yönlü etkisi $(, 312)$ bulunmaktadır (Tablo6).

Motivasyonun hangi boyutlarının yaşam doyumu üzerinde ne derece etkisi olduğu ayrıca araştırılmış ve Şekil 3'te model gösterilmiştir. Modelin uyum değerleri ki kare nin serbestlik derecesi, RMSEA değeri ve CFI, GFI, NFI değerleri kabul edilebilir seviyede bulunmuştur ( $\chi 2$ /sd: 2,577 ; GFI:0,96; NFI: 0,94; CFI: 0,96; RMSEA: 0,072).

Şekil 3

Motivasyon Boyutlarının Yaşam Doyumuna Etkisi

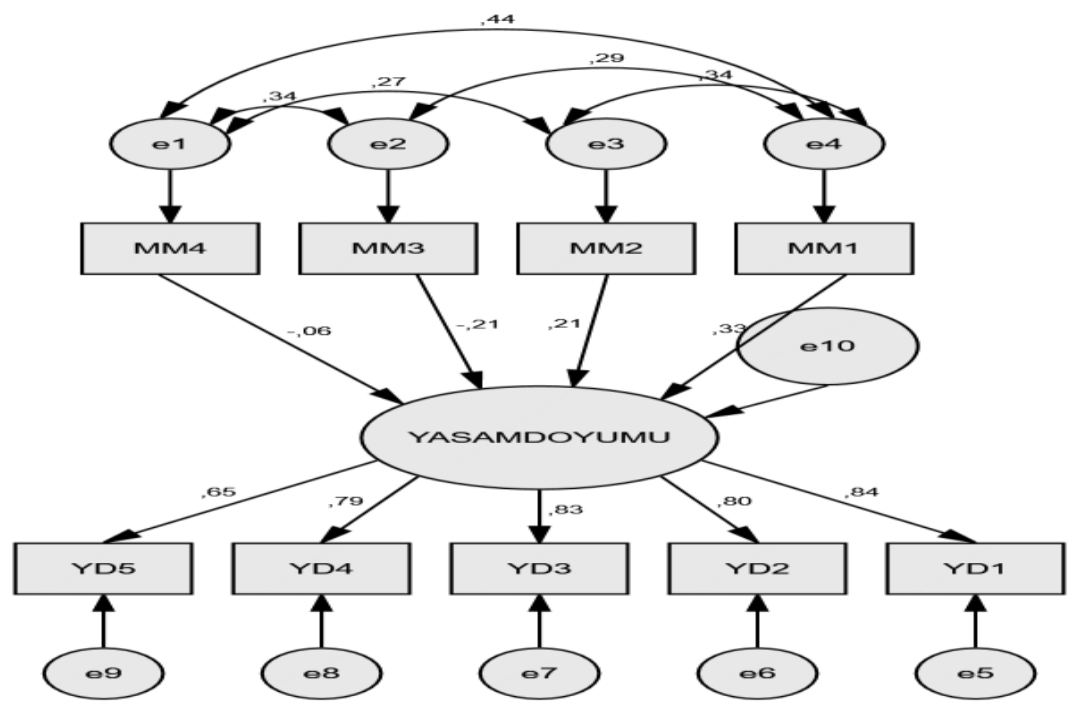




\section{IIIII)}

Turist Rehberliği Dergisi (TURED) \& Yıl. 2021, Cilt. 4, Sayı. 1

Journal of Tour Guiding (JOTOG) \& Year. 2021, Volume. 4, Issue. 1

Tablo 7

Motivasyon Boyutlarının Etki Değerleri

\begin{tabular}{lllrrr}
\hline & & & $\begin{array}{l}\text { Standart } \\
\text { Regresyon } \\
\text { Değerleri }\end{array}$ & Std. Hata & $\mathrm{p}$ \\
\hline YASAMDOYUMU & $<---$ & MM4 &,- 059 &, 073 &, 359 \\
YASAMDOYUMU & $<---$ & MM3 &,- 206 &, 053 & $* * *$ \\
YASAMDOYUMU & $<---$ & MM2 &, 207 &, 048 & $* * *$ \\
YASAMDOYUMU & $<---$ & MM1 &, 333 &, 083 & $* * *$ \\
\hline
\end{tabular}

***p $<0,05$ düzeyinde anlamlıdır.

Motivasyonun yaşam doyumu üzerindeki etkisi boyutlar bazında incelendiğinde ilk boyut olan (MM1) eğlence motivasyonunun yaşam doyumu üzerinde en etkili regresyon değerine $(, 333)$ sahip olduğu saptanmıştır. $\mathrm{Bu}$ durumda işini eğlenerek yapan turist rehberlerinin yaşam doyumlarının pozitif anlamda etkileneceğini belirtmek mümkündür.

\section{Sonuç}

Bu çalışma kapsamında Covid-19 döneminde profesyonel turist rehberlerinin çalışma motivasyonlarının yaşam doyumlarına olan etkisi araştırılmıştır. Çalışma motivasyonu ve yaşam doyumu kavramları, rehberin kendisini iyi hissetmesini, motive çalışmasını, turlardaki performansını, turist memnuniyetini direkt etkileyen faktörlerdendir. Bu konunun araştırılması hem rehberlerin mevcut durumunun analizi hem de turist memnuniyetine katkı sağlaması açısından önemlidir.

Ölçek analizlerine geçilmeden önce verilerin normal dağılımını görmek için çarpıklık basıklık değerleri test edilmiş ve çıkan değerler literatürle uygun bulunmuştur. Ölçeklere göre demografik özelliklerin fark gösterip göstermediğinin açıklanması için yapılan $\mathrm{t}$ testi ve Anova testi sonucunda, motivasyon ölçeğinin evli olan katılımcılarda $(\overline{\mathrm{x}}: 5,48)$ ve $20-35$ yaş aralığındaki katılımcılarda $(\overline{\mathrm{x}}: 5,51)$ daha yüksek olduğu saptanmıștır. Yaşam doyumu ölçeği incelendiğinde evli olan turist rehberlerinin yaşam doyumunu daha yüksek hissettiğini belirtmek mümkündür ( $\overline{\mathrm{x}}: 5,03)$. Ölçek yapılarını test etmek amacıyla yapılan açıklayıcı faktör analizi ile motivasyonun 4 boyutlu yapısı ve yaşam doyumunun tek boyutlu yapısı literatürle uyumluluk göstermiştir. Doğrulayıcı faktör analizi ile motivasyon ölçeği faktör yapısı doğrulanmıştır. Motivasyon ölçeğinde öne çıkan boyutun ilk faktör olan eğlence motivasyonu olduğu belirlenmiştir. Ancak Erkol Bayram (2017) ve Köroğlu ve Avcıkurt (2014) çalışmalarında turist rehberlerinin ekonomik araçlarla (ödül, ücret...) motive olduklarını açıklamışlardır. Bu araşıımada ise ödül ve ekonomik araçları açıklayan 4.motivasyon boyutu motivasyonu açıklayan en az yüzdeye sahiptir (\%8,389). Araştırmanın yürütüldügüu dönemde yaşanan Covid-19 salgını nedeniyle geçen yılın aynı dönemine göre (Ocak-Eylül 2019) toplam ziyaretçi sayısında \%71,3 azalış yaşanmıştır (T.C. Kültür ve Turizm Bakanlığı, 2020). Bu durumda iş alamayan turist rehberlerinin ekonomik beklentilerinin düştüğ̈̈, bu nedenle motivasyon araçlarının bu döneme özel değişiklik gösterdiğini belirtmek mümkündür. Yalnızca işini devam ettirebilmek, çalışabilmek bile rehberlerin iç motivasyonunu arttırmıştır. Creswell \& Ekmund (2005), Hsu (2013), içsel motivasyonun önemine dikkat çekerek içsel motivasyonun yüksek olması halinde bireyin kendini iyi hissedeceğini ve tükenmişlik ile daha az yüz yüze kalacağını; Janssen vd., (1999) içsel motivasyonun işin sonucundan ziyade işin kendisiyle ilgili olduğunu belirtmektedirler.

Motivasyon ve yaşam doyumu arasındaki ilişki ve etki durumunu görmek için yapısal eşitlik modellemesi yapılmıştır. Buna göre, motivasyonun yaşam doyumu üzerinde pozitif $(, 312)$ yönlü etkisinin olduğu ortaya konmuştur. Bu bağlamda eğer turist rehberlerinin çalışma motivasyonu yüksek olursa yaşam doyumlarını da yüksek hissedeceklerdir. Motivasyon ve yaşam doyumu arasındaki iliş̧iyi araştıran çalışmalar (Salinas-Jimenez vd., 2010; Kwak vd., 2013; Mafini \& Dlodlo, 2014; Marco Alexandre vd., 2017) bu sonucu desteklemektedir. 
Bu çalışma yapıldığı dönem ve örneklem boyutuyla sınırlı kalabilmektedir. Farklı dönem ve örneklem boyutuyla, araştırmacılar farklı sonuçlar alabilirler.

\section{Kaynakça}

Akgündüz, Y. (2013). Konaklama işletmelerinde iş doyumu, yaşam doyumu ve öz yeterlilik arasındaki ilişkinin analizi. CBÜ Sosyal Bilimler Dergisi, 11(1), 180-204.

Alrawadieh, Z., Çetin, G., Dinçer, M.Z. \& İstanbullu Dinçer, F. (2018, Haziran 25-29). Exploring quality of work life and life satisfaction of tour guides: An emotional labor perspective [Konferans Sunumu]. $8 \mathrm{Th}$ Advances in Hospitality and Tourism Marketing and Management (Ahtmm) Conference Proceedings, Bangkok-Thailand.

Appleton, S. \& Song, L. (2008). Life satisfaction in urban China: Components and determinants. World Development, 36(11).

Avşaroğlu, S., Deniz, M. E. \& Kahraman, A. (2005). Teknik öğretmenlerde yaşam doyumu, iş doyumu ve mesleki tükenmişlik düzeylerinin incelenmesi. Selçuk Üniversitesi Sosyal Bilimler Enstitüsü Dergisi, 14, 115-129.

Azar, M. \& Shafighi, A. A. (2013). The effect of work motivation on employees' job performance (Case study: Employees of isfahan Islamic revolution housing foundation). International Journal of Academic Research in Business and Social Sciences. 3(9) 432-445.

Baltacı, A. (2018). Nitel araştırmalarda örnekleme yöntemleri ve örnek hacmi sorunsalı üzerine kavramsal bir inceleme. Bitlis Eren Üniversitesi Sosyal Bilimler Enstitüsü Dergisi. 7(1): 231-274.

Can, M. \& Koç, H. (2018). Tools of motivation according to the competing values framework in organizational culture types: An implementation in accommodation establishments. Afyon Kocatepe University Journal of Social Sciences. 20(3), 251-260.

Cresswell, S. L. \& Eklund, R. C. (2005). Motivation and burnout among top amateur rugby players. Medicine and Science in Sports and Exercise, 37(3), 469-477.

Çivilidağ, A. \& Şekercioğlu, G. (2017). Çok boyutlu iş motivasyonu ölçeğinin Türk kültürüne uyarlanmas1. Mediterranean Journal of Humanities, 7(1), 143-156.

Diener, E., Emmons, R.A., Larsen, R.J. \& Grıffin, S. (1985). The satisfaction with life scale. Journal of Personality Assessment. 49(1): 71-75.

Dikmen, A.A. (1995). İş doyumu ve yaşam doyumu ilişkisi. Ankara Üniversitesi Siyasal Bilgiler Fakültesi Dergisi, 50(3-4), 115-140.

Dünya Sağlık Örgütü (2021), https://covid19.who.int, Erişim Tarihi: 15.03.2021.

Düzgün, E. \& Kurt, A. (2020). Covid-19 (Koronavirüs) salgınının turist rehberleri üzerindeki etkileri: Ankara turist rehberleri odası örneği. Karadeniz Sosyal Bilimler Dergisi, 12(23), 301-321.

Erkol Bayram, G. (2017). Motivasyonun demografik ve mesleki özelliklere göre farklılaşması: Turist rehberleri üzerine bir araştırma. Journal of Yasar University. 12(48), 257-271.

Erkol, G. (2015). Mobbing ve motivasyon arasındaki ilişki: Turist rehberleri üzerine bir araştırma [Yayınlanmamış Doktora Tezi]. Sakarya Üniversitesi.

George, D., \& Mallery, M. (2010). Spss for windows step by step: A simple guide and reference. 17.0 Update (10. Ed.). Pearson.

Hair, J. F., Black, W. C., Babın, B. J., Anderson, R. E. \& Tatham, R. L. (2013). Multivariate data analysis. Pearson Education Limited.

Haque, T. H., \& Haque, M. O. (2018). The swine flu and its impacts on tourism in Brunei. Journal of Hospitality and Tourism Management, 36, 92-101.

Hsu, L. (2013). Work motivation, job burnout, and employment aspiration in hospitality and tourism students: An exploration using the self-determination theory. Journal of Hospitality, Leisure, Sport \& Tourism Education, 13, 180-189.

Huggins, K. A., White, D. W. \& Stahl, J. (2016). Antecedents to sales force job motivation and performance: The critical role of emotional intelligence and affect-based trust in retailing managers. International Journal of Sales, Retailing and Marketing, 5(1), 27-37. 
Ingram, T. N., Lee, K. S. \& Skinner, S. J. (1989). An emprical assessment of saleperson motivation, commitment and job outcomes. Journal of Personal Selling- Sales Management, 9, 25-33.

İbiş, S. (2020). Covid-19 salgınının seyahat acentaları üzerine etkisi. Safran Kültür ve Turizm Araştırmaları Dergisi, 3(1), 85-98.

İlhan, Y. \& Soybalı, H. H. (2018). Turist rehberlerinin mesleki sorunları üzerine bir araştırma. Turist Rehberliği Dergisi, 1(1), 13-23.

Janssen, P.P.M., Jonge, J. \& Bakker, A.B. (1999). Specific determinants of intrinsic work motivation, burnout and turnover intentions: A study among nurses. Journal of Advanced Nursing, 29(6), 1360-1369.

Joo, H., Maskery, B. A., Berro, A. D., Rotz, L. D., Lee, Y. K., \& Brown, C. M. (2019). Economic impact of the 2015 MERS uutbreak on the Republic of Korea's tourism-related industries. Health Security, 17(2), 100-108.

Kara, F. M., Kelecek, S. \& Aşçı, F.H. (2014). Sporcu eşlerinin yaşam doyumu ve yalnızlık düzeylerinin Iincelenmesi. Spor Bilimleri Dergisi Hacettepe 2014, 25(2), 56-66.

Keser, A. (2011). Çalışma yaşamı ile yaşam doyumu ilişkisine teorik bakış. İstanbul Üniversitesi İktisat Fakültesi Mecmuası, 55(1), 897- 913.

Koçel, T. (2018). İsletme yöneticiliği: Yönetim ve organizasyon, organizasyonlarda davranış, klasikmodern, çağdaş ve güncel yaklaşımlar (17. baskı). Beta Yayıncılık.

Kongoley-Mih, P. S. (2014). The impact of ebola on the tourism and hospitality industry in Sierra Leone. International Journal of Scientific and Research Publications, 5(12), 542-550.

Köroğlu, Ö. \& Avcıkurt, C. (2014). Turist rehberlerinin motivasyonu ile performansı arasındaki ilişkinin belirlenmesi. Dumlupınar Üniversitesi Sosyal Bilimler Dergisi. 39, 45-60.

Köse, E. (2019). Çalıșanların iș tatmini algıları ile iș motivasyonu düzeyleri arasındaki ilișkinin araştırılması. Bilecik Şeyh Edebali Üniversitesi Sosyal Bilimler Enstitüsü Dergisi. 4(1), 131-148.

Kwok, Y. Y., Chui, W.H. \& Wong, L.P. (2013). Need satisfaction mechanism linking volunteer motivation and life satisfaction: A mediation study of volunteers subjective well-being. Social Indicators Research, 114(3), 1315-1329.

Mafini, C. \& Dlodlo, N. (2014). The relationship between extrinsic motivation, job satisfaction and life satisfaction amongst employees in a public organisation. SA Journal of Industrial Psychology, $40(1), 1-13$.

Marco Alexandre, S.B., Ruth, J.C., Marta, L.R., Maria Isabel, A.C. \& Susana, L.M. (2017). Selfdetermined motivation and life satisfaction in Portuguese veterans athletes. Nuevas Tendencias En Educación Física, Deporte Y Recreación, 32, 124-129.

Miao, C.F., Evans, K.R. \& Zou, S. (2007). The role of salesperson motivation in sales control systems -intrinsic and extrinsic motivation revisited. Journal of Business Research 60, 417-425.

Putra, T. R. I. (2019). The role of organization climate and work motivation on job satisfaction in aceh government health office. Journal of Academic Research In Economics, 11(1), 98-106.

Salınas- Jimenez, M. M., Artes, J. \& Salınas- Jimenez, J. (2010). Income, motivation, and satisfaction with life: An empirical analysis. Journal of Happiness Studies, 11, 779-793.

T.C. Kültür ve Turizm Bakanlığ (2020), https://yigm.ktb.gov.tr/TR-9851/turizm-istatistikleri.html, Erişim Tarihi: 27.10 .2020

Tabachnick, B. G. \& Fidell, L.S. (2013) Using multivariate statistics. (6. Ed.). Pearson.

Türkiye Turist Rehberleri Birliği (2020), http://www.tureb.org.tr/tr/Notices/Detail/948, Erişim Tarihi: 27.10 .2020

Uzonna, U. R. (2013). Impact of motivation on employees' performance: A case study of creditwest bank Cyprus. Journal of Economics And International Finance. 5(5), 199-211.

Ülker Tümlü, G. \& Recepoğlu, E. (2013). Üniversite akademik personelinin psikolojik dayanıklılık ve yaşam doyumu arasındaki ilişki. Yüksekögretim ve Bilim Dergisi. 3(3), 205-213.

Ünal, S., Karlıdağ, R. \& Yoloğlu S. (2001). Hekimlerde tükenmişlik ve iş doyumu düzeylerinin yaşam doyumu düzeyleri ile ilişkisi. Klinik Psikiyatri. 4, 113-118. 
Turist Rehberliği Dergisi (TURED) \& Yıl. 2021, Cilt. 4, Sayı. 1

Journal of Tour Guiding (JOTOG) \& Year. 2021, Volume. 4, Issue. 1

Veenhoven, R. (1996). The study of life satisfaction W.E. Saris, R. Veenhoven, A.C. Scherpenzeel, B. Bunting (Eds.), A comparative study of satisfaction with life in Europe, Eötvös University Press, Budapest (1996), 11-48.

Wen, Z., Huimin, G., \& Kavanaugh, R. R. (2005). The impacts of SARS on the consumer behaviour of Chinese domestic tourists. Current Issues in Tourism, 8(1), 22-38.

Yeşil, A. (2016). Liderlik ve motivasyon teorilerine yönelik kavramsal bir inceleme. Uluslararası Akademik Yönetim Bilimleri Dergisi. 2(3), 158-180.

\section{ETIKK ve BILLIMSEL ILKELER SORUMLULUK BEYANI}

Bu çalışmanın tüm hazırlanma süreçlerinde (veri toplama, yazım vb.), tüm etik kurallara ve bilimsel atıf gösterme ilkelerine riayet edildiğini, herhangi bir hataya mahal vermemek için yayımdan önce makalenin bir intihal programı aracılığıyla da kontrol edildiğini yazarlar beyan eder. Ayrıca yazarlar aşağıda sıralanan hususları kabul etmiștir:

1. Çalışmada yer alan ve kullanılan tüm kaynaklara, bilimsel araştırma yöntemleri ve etik ilkeler doğrultusunda atıf yapılmıştır.

2. Çalışmada tüm yazarların akademik-bilimsel olarak doğrudan ve ortak katkısı vardır.

3. Bu çalıșma, yazarların özgün bir çalıșmasıdır.

4. Bütün yazarlar dergiye gönderilen makaleyi görmüş ve sonuçlarını onaylamıştır.

5. Çalışmada kullanılan denek/deneklere ilişskin herhangi bir etik ihlal yapılmamış, kullanılan tüm veri toplama yöntemlerinde bilimsel etik ilkelere göre hareket edilmiştir.

6. Çalışma daha önceden bilimsel bir toplantıda sunulan özet veya bu çalışmanın daha kısa hali ise, makalede bu durum belirtilmiştir.

7. Çalıșmada, hiçbir suç unsuru veya kanuna aykırı ifade bulunmamakla birlikte, araştırma yapılırken kanuna aykırı herhangi bir yöntem kullanılmamış olup, çalışma ile ilgili tüm yasal izinler alınmış ve etik kurallara uygun hareket edilmiştir.

Aksi bir durumun tespiti halinde Turist Rehberliği Dergisi’nin hiçbir sorumluluğu olmayıp, tüm sorumluluk makale yazarlarına aittir.

Tarih : : $17 / 03 / 2021$

Sorumlu Yazar : Öznur ÇETINKAYA 